\title{
Perancangan dan Implementasi Pengontrol Arah Pancaran Radar Pengawas Pantai Terhadap Sudut Tertentu
}

\section{Design and Implementation of Radar Beam Direction to a Certain Angle on The Coastal Radar}

\author{
Dadin Mahmudin ${ }^{a,}$, Andri Setya Dharma ${ }^{b}$, Erwin Susanto ${ }^{b}$, dan Yuyu Wahyu ${ }^{a}$ \\ ${ }^{a}$ Pusat Penelitian Elektronika dan Telekomunikasi, Lembaga Ilmu Pengetahuan Indonesia. \\ Komp LIPI Gd 20, Jl Sangkuriang 21/54D, Bandung 40135, Indonesia \\ ${ }^{b}$ Departemen Elektro dan Komunikasi - Universitas Telkom \\ Jl. Telekomunikasi, Dayeuhkolot Bandung 40257 Indonesia
}

\begin{abstract}
Abstrak
Dewasa ini sudah banyak dilakukan penelitian dan pengembangan radar. Salah satunya adalah radar yang ditempatkan di kapal laut. Tiang-tiang yang terdapat di kapal laut akan mengganggu fungsi dari radar tersebut. Tiang akan mengganggu fungsi radar karena adanya pantulan sinyal jarak dekat pada tiang agung. Hal ini dapat diantisipasi dengan mematikan pancaran radar saat arah pancaran radar menuju pada tiang agung kapal laut.

Oleh sebab itu di dalam penelitian ini dirancang prototipe untuk mengatur otomatis aktif dan tidaknya pancaran radar berdasarkan arah pancaran radar. Kontrol aktif dan tidaknya pancaran radar ini dikontrol menggunakan perpaduan sensor ultrasonik dan sensor kompas dengan dilengkapi metode fuzzy sebagai logika jauh dekatnya tiang agung. Jika sensor ultrasonik membaca adanya halangan maka pancaran tidak aktif, begitu juga sebaliknya. Penggabungan kedua sensor ini bertujuan jika sensor ultrasonik tidak dapat bekerja karena hujan maka kontrol sudut pada sensor kompas yang akan bekerja.

Setelah dilakukan perancangan dan pengujian pada alat ini maka diperoleh sudut deviasi dengan rentang $14,3-29,3^{\circ}$ dengan error $\pm 3^{\circ}$. Dengan acuan jangkauan titik tiang agung $60-120 \mathrm{~cm}$ dari poros radar dengan lebar tiang $30 \mathrm{~cm}$. Kecepatan yang diperoleh saat fuzzy berlangsung sebesar 20 kali dari kecepatan normal saat prototipe mengenai halangan. Serta adanya sensor hujan berperan sebagai switch sensor ultrasonik ke mode off dan mode on untuk sensor kompas dengan menggunakan inisialisasi awal. Dari data yang dihasilkan, keberhasilan prototipe ini sebesar 85\% dilihat dari pengujian beberapa sensor dan peggabungannya. Oleh sebab itu apabila prototipe ini direalisasikan akan membantu penelitian industri perkapalan dalam pembuatan radar sesungguhnya.
\end{abstract}

Kata kunci: sensor ultrasonik, prototipe, fuzzy, kompas.

\section{Abstract}

Today research and development of radar have been done. One is a Radar that is used on Naval. Pillars on Naval will disturb the function of Radar. It will disturb radar function due to the reflection of radar signal at close range on this pillar. It can be anticipated by turning off radar transmitter when transmits directly toward pillar.

Therefore, in this research a prototype is designed to automatically set turning on or turning off radar transmission based on transmitted radar direction. Active and deactivate radar transmitter is controlled by combining ultrasonic sensor and compass sensor with fuzzy method as far and near distance pillar. If the ultrasonic sensor detects an obstacle the radar transmitter will be inactive and otherwise. The aim of combining the two sensors is to activate the compass sensor if ultrasonic sensor is not working properly due to the rain.

After designing and testing of the prototype, it is then obtained the deviation axis range of $14,3-29,3^{\circ}$ with error $\pm 3{ }^{\circ}$. The distance reference of pillar of 60-120 cm from radar axis with pillar width of $30 \mathrm{~cm}$. Fuzzy speed is obtained 20 times faster than normal condition when radar prototype finds a pillar. Rain detector will switch off the ultrasonic sensor and switch on compass sensor for start inisialisasion. The prototype is obtained success of $85 \%$. Therefore, if realized this prototype will support the shipping industry in the manufacture of Radar.

Keywords: ultrasonic sensor, prototype, fuzzy, compass.

\section{Pendahuluan}

Sekarang ini di Indonesia sedang dikembangkan radar pengawas pantai untuk pengamanan dan pengawasan wilayah NKRI yang terdiri dari kurang lebih 17.504 pulau dengan 2/3 wilayah terdiri dari lautan [1]. Radar buatan dalam negeri ini menggunakan teknologi Frequency Modulated Continuous Wave (FM-CW), yaitu suatu teknologi radar yang mentransmisikan sinyal secara terus menerus dan menggunakan dua antena terpisah untuk pemancar dan penerima [2]. Untuk mengantisipasi jangkauan radar yang tidak dapat menjangkau daerah yang jauh dari bibir

* Corresponding Author.

Email: dradrin@gmail.com, esdetrans@gmail.com

Received: May 28, 2014; Revised: June 12, 2014

Accepted: June 23, 2014

Published: June 30, 2013

(C) 2014 PPET - LIPI

doi : 10.14203/jet.v14.29-35 pantai, maka diperlukan penempatan radar di kapal laut.

Penempatan radar di atas kapal laut mempunyai beberapa kendala. Radar harus ditempatkan pada tempat terbuka, sedangkan di kapal laut terdapat banyak tiang/pilar. Salah satu tiang kapal laut yang sangat mengganggu adalah tiang agung kapal laut. Tiang agung 
adalah tiang terbesar yang berada di tengah kapal laut. Tiang agung ini mengganggu pancaran radar, karena tiang agung dapat memantulkan kembali sinyal yang dapat merusak sistem kerja pada radar [3].

Mengacu permasalahan di atas maka dibutuhkan sistem atau alat yang bekerja mematikan pancaran radar saat arah pancaran menuju tiang agung dan tentunya sistem ini tidak mengganggu proses berputarnya radar. Sebelum pembuatan sistem sesungguhnya perlu dibuat sebuah rupa-rupa sistem tersebut untuk percobaan sebelum diimplementasikan.

Pengontrol yang digunakan pada sistem ini berupa mikrokontroler ATMega 32 dengan sensor ultrasonik SR-04 dan sensor kompas CMPS10 dengan menggunakan metode logika fuzzy. Penerapan logika fuzzy pada sistem ini terletak pada pengaturan jarak tiang terhadap kecepatan putar motor servo. Pengontrolan ini diintegrasikan ke rangkaian LED sebagai indikator pancaran radar. Jika sensor ultrasonik membaca adanya halangan maka LED akan aktif begitu juga sebaliknya. Sistem ini juga dilengkapi dengan sensor hujan untuk membaca kondisi yang sedang berlangsung. Pada alat ini akan dicoba 4 kondisi, yaitu : kondisi tidak hujan belum inisialisasi, kondisi belum hujan sudah inisialisasi, kondisi hujan belum inisialisasi dan kondisi hujan sudah inisialisasi. Dalam alat ini dilengkapi dengan LCD alfanumerik yang berguna untuk menampilkan kondisi sudut deviasi dan jarak sehingga bisa dikontrol jika alat tidak sesuai dengan kondisi yang sedang berlangsung.

Setelah perancangan sistem ini terlaksana maka didapatkan beberapa hasil pengujian dan analisis pengujian. Dari semua pengujian diperoleh set point 0 dengan kisaran $356-4^{\circ}$. Dengan didapatkan sudut deviasi tiang dengan kisaran ordinat 14,3-29,3 $3^{\circ}$ dengan error $\pm 3^{\circ}$. Percobaan dilakukan 8 kali dengan lebar tiang $30 \mathrm{~cm}$ dan jangkauan utrasonik 60-120 cm. Berdasarkan pada hasil pengujian tersebut diperoleh bahwa pengujian sebanding dengan perbandingan teori perhitungan trigonometri penerapan rumus pitagoras. Sedangkan logika fuzzy menggunakan 3 parameter fuzzy senilai $80 \mathrm{~cm}, 140 \mathrm{~cm}$, dan $200 \mathrm{~cm}$ untuk mengatur kecepatan motor servo. Kecepatan yang diperoleh saat fuzzy berlangsung sebesar 20 kali dari kecepatan normal. Dari data yang dihasilkan, prototipe ini memperoleh keberhasilan sebesar $85 \%$ dilihat dari pengujian beberapa sensor dan penggabungannya. Dari data yang dihasilkan prototipe ini diharapkan sebagai acuan dalam pembuatan radar sesungguhnya.

\section{TEORI DASAR}

\section{A. Sistem Kendali}

Sistem Kendali atau control system terdiri dari dua kata yaitu system dan control. System berasal dari Bahasa Latin (systēma) atau bahasa Yunani (sustēma) adalah suatu kesatuan yang terdiri dari komponen atau elemen yang dihubungkan bersama untuk mencapai suatu tujuan tertentu. Control itu memiliki arti mengatur, mengarah dan mengendalikan [4], [5]. Jadi system control adalah hubungan antara komponenkomponen fisik yang membentuk suatu konfigurasi sistem sehingga memberikan hasil yang diharapkan.
Hubungan antara input dan output pada sistem menunjukkan adanya hubungan sebab akibat dari sebuah proses, yang berawal dari input sampai bisa menghasilkan output. Maksud dari sistem kendali adalah menetapkan atau mendefinisikan input dan output. Jika input dan output telah ditentukan, maka memungkinkan untuk menetapkan atau mendefinisikan sifat dari komponen-komponen sistem tersebut. Jenisjenis sistem kendali terdiri dari 2 macam yaitu sistem untaian terbuka (open loop) dan sistem untaian tertutup (closed loop) [6].

\section{1) Sistem Untaian Terbuka (open loop)}

Sistem kendali untaian terbuka adalah sebuah sistem yang tidak memiliki umpan balik (feedback), sehingga bila terdapat gangguan dari dalam maupun dari luar maka sistem tidak dapat melaksanakan tugas seperti yang diharapkan. Suatu sinyal masukan diberikan ke dalam sistem kendali di mana keluarannya bertindak sebagai sinyal penggerak. Sinyal penggerak ini yang kemudian menghasilkan proses yang akan dikendalikan sehingga menghasilkan output yang diinginkan. Proses untaian terbuka dapat dilihat pada Gambar 1.

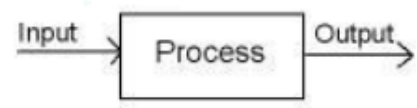

Gambar 1. Sistem Pengendalian Untaian Terbuka.

\section{2) Sistem Untaian Tertutup (Closed Loop)}

Sistem kendali untaian tertutup (closed loop) adalah sistem kontrol yang memiliki umpan balik, berbeda dengan sistem untaian terbuka. Pada bagian output dari sistem kontrol ini akan dikirim kembali untuk dibandingkan dengan input yang diberikan. Bila masih terdapat selisih antara output dan input, maka sistem masih memiliki error. Proses kerja dari sistem untaian tertutup dapat dilihat pada Gambar 2.

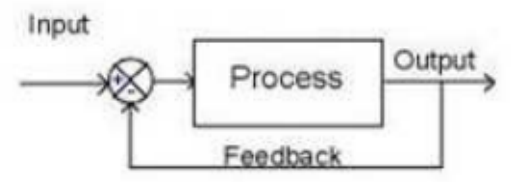

Gambar 2. Sistem Pengendalian Untaian Tertutup.

\section{B. Logika Fuzzy}

\section{1) Pengertian Logika Fuzzy}

Fuzzy secara bahasa diartikan sebagai kabur atau samar-samar. Suatu nilai dapat bernilai benar atau salah secara bersamaan. Dalam fuzzy dikenal derajat keanggotaan yang memiliki rentang nilai 0 (nol) hingga 1 (satu). Berbeda dengan himpunan tegas yang memiliki nilai 1 atau 0 (ya atau tidak).

Logika fuzzy merupakan suatu logika yang memiliki nilai kekaburan atau kesamaran (fuzzyness) antara benar atau salah. Logika fuzzy memiliki derajat keanggotaan dalam rentang 0 hingga 1 . Berbeda dengan logika digital yang hanya memiliki dua nilai 1 atau 0 . Logika fuzzy digunakan untuk menerjemahkan suatu besaran yang diekspresikan menggunakan bahasa 
(linguistik), misalkan besaran kecepatan laju kendaraan yang diekspresikan dengan pelan, agak cepat, cepat, cepat, dan sangat cepat. Dan logika fuzzy menunjukkan sejauh mana suatu nilai itu benar dan sejauh mana suatu nilai itu salah. Tidak seperti logika klasik/tegas, suatu nilai hanya mempunyai 2 kemungkinan yaitu merupakan suatu anggota himpunan atau tidak. Derajat keanggotaan 0 (nol) artinya nilai bukan merupakan anggota himpunan dan 1 (satu) berarti nilai tersebut adalah anggota himpunan.

Logika fuzzy adalah suatu cara yang tepat untuk memetakan suatu ruang input ke dalam suatu ruang output, mempunyai nilai kontinyu. Fuzzy dinyatakan dalam derajat dari suatu keanggotaan dan derajat dari kebenaran. Oleh sebab itu sesuatu dapat dikatakan sebagian benar dan sebagian salah pada waktu yang sama [4].

Logika fuzzy memungkinkan nilai keanggotaan antara 0 dan 1, tingkat keabuan dan juga hitam dan putih, dan dalam bentuk linguistik, konsep tidak pasti seperti "sedikit", "lumayan", dan "sangat". Kelebihan dari teori logika fuzzy adalah kemampuan dalam proses penalaran secara bahasa (linguistic reasoning). Sehingga dalam perancangannya tidak memerlukan persamaan matematika dari objek yang akan dikendalikan.

\section{2) Perbedaan Logika Fuzzy dengan Logika Tegas}

Perbedaan antara kedua jenis logika tersebut adalah logika tegas memiliki nilai tidak $=0$ dan ya $=1$, sedangkan logika fuzzy memiliki nilai antara 0 hingga 1 . Secara grafik perbedaan antara logika tegas dan logika fuzzy ditunjukkan oleh gambar di bawah ini:
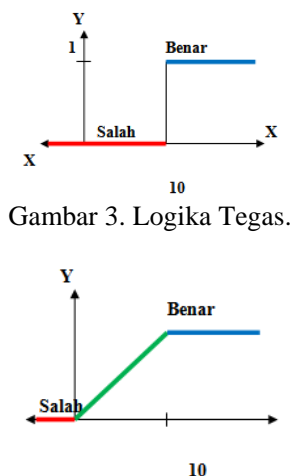

Gambar 4. Logika Fuzzy.

Dalam Gambar 3 apabila $X$ lebih dari atau sama dengan 10 baru dikatakan benar yaitu bernilai $\mathrm{Y}=1$, sebaliknya nilai $\mathrm{X}$ yang kurang dari 10 adalah salah yaitu $\mathrm{Y}=0$. Maka angka 9 atau 8 atau 7 dan seterusnya adalah dikatakan salah.

Dalam Gambar 4 nilai $X=9$ atau 8 atau 7 atau nilai antara 0 dan 10 adalah dikatakan ada benarnya ada juga salahnya.

\section{3) Fungsi Keanggotaan}

Fungsi keanggotaan adalah suatu kurva yang menunjukkan pemetaan titik-titik input data ke dalam nilai keanggotaannya (sering juga disebut dengan derajat keanggotaan) yang memiliki interval antara 0 sampai 1. Salah satu cara yang dapat digunakan untuk mendapatkan nilai keanggotaan adalah dengan melalui pendekatan fungsi. Apabila $U$ menyatakan himpunan universal dan A adalah himpunan fungsi fuzzy dalam $\mathrm{U}$, maka A dapat dinyatakan sebagai pasangan terurut. Ada beberapa fungsi yang bisa digunakan.

\section{a) Representasi linear}

Pada representasi linear, pemetaan input ke derajat keanggotaannya digambarkan sebagai suatu garis lurus. Bentuk ini paling sederhana dan menjadi pilihan yang baik untuk mendekati suatu konsep yang kurang jelas.

Ada 2 keadaan himpunan fuzzy yang linear. Pertama, kenaikan himpunan dimulai pada nilai domain yang memiliki derajat keanggotaan nol (0) bergerak ke kanan menuju ke nilai domain yang memiliki derajat keanggotaan lebih tinggi (Gambar 5).

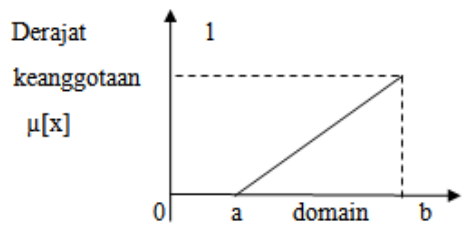

Gambar 5. Representasi Linear Naik.

Fungsi Keanggotaan:

$$
\mu[\mathrm{x}]=\left\{\begin{array}{cc}
0 ; & \mathrm{x} \leq \mathrm{a} \\
\frac{\mathrm{x}-\mathrm{a}}{\mathrm{b}-\mathrm{a}} ; & \mathrm{a}<\mathrm{x}<\mathrm{b} \\
1 ; & \mathrm{x} \geq \mathrm{b}
\end{array}\right.
$$

Kedua, merupakan kebalikan dari yang pertama. Garis lurus dimulai dari nilai domain dengan derajat keanggotaan tertinggi pada sisi kiri, kemudian bergerak menurun ke nilai domain yang memiliki derajat keanggotaan lebih rendah (Gambar 6).

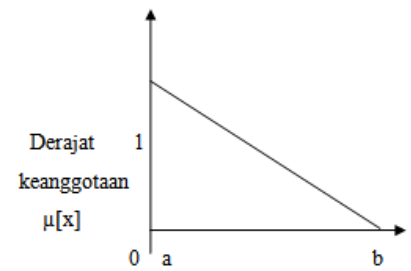

Gambar 6. Representasi Linear Turun

Fungsi Keanggotaan:

$$
\mu[\mathrm{x}]=\left\{\begin{array}{cc}
0 ; & \mathrm{x} \geq \mathrm{b} \\
\frac{\mathrm{b}-\mathrm{x}}{\mathrm{b}-\mathrm{a}} ; & \mathrm{a}<\mathrm{x}<\mathrm{b} \\
1 ; & \mathrm{x} \leq \mathrm{a}
\end{array}\right.
$$

b) Representasi kurva segitiga

Kurva segitiga pada dasarnya merupakan gabungan antara 2 garis (linear) (Gambar 7).

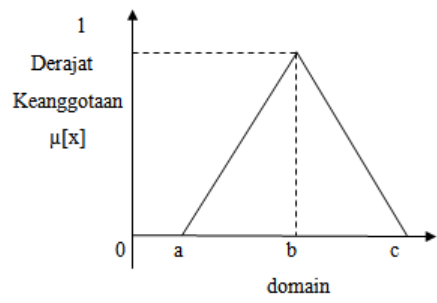

Gambar 7. Representasi Kurva Segitiga. 
Fungsi Keanggotaan:

$$
\mu[\mathrm{x}]=\left\{\begin{array}{lc}
0 ; \quad \mathrm{x} \geq \mathrm{c} \text { atau } \mathrm{x} \leq \mathrm{a} \\
\frac{\mathrm{x}-\mathrm{a}}{\mathrm{b}-\mathrm{a}} ; \quad \mathrm{a}<\mathrm{x}<\mathrm{b} \\
\frac{\mathrm{c}-\mathrm{x}}{\mathrm{c}-\mathrm{b}} ; \quad \mathrm{b}<\mathrm{x}<\mathrm{c}
\end{array}\right.
$$

\section{c) Representasi kurva trapesium}

Kurva trapesium pada dasarnya seperti bentuk segitiga, hanya saja ada titik yang memiliki nilai keanggotaan 1 (Gambar 8).

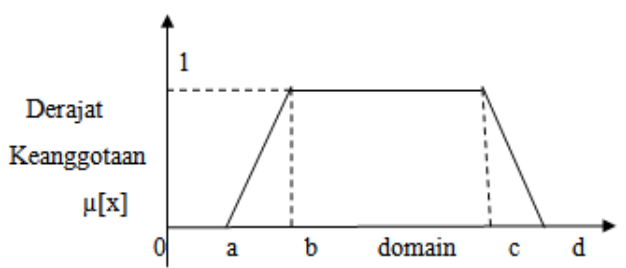

Gambar 8. Representasi Kurva Trapesium.

Fungsi Keanggotaan:

$$
\mu[\mathrm{x}]=\left\{\begin{array}{cc}
0 ; & \mathrm{x} \geq \mathrm{d} \text { atau } \mathrm{x} \leq \mathrm{a} \\
\frac{\mathrm{x}-\mathrm{a}}{\mathrm{b}-\mathrm{a}} ; & \mathrm{a}<\mathrm{x}<\mathrm{b} \\
\frac{\mathrm{d}-\mathrm{x}}{\mathrm{d}-\mathrm{c}} ; & \mathrm{c}<\mathrm{x}<\mathrm{d} \\
1 ; & \mathrm{b} \leq \mathrm{x} \leq \mathrm{c}
\end{array}\right.
$$

\section{4) Fuzzifikasi}

Fuzzifikasi adalah suatu fase di mana terjadi pengubahan masukan-masukan yang nilai kebenarannya bersifat pasti (crisp input) ke dalam bentuk fuzzy input berupa nilai linguistik, yang semantiknya ditentukan berdasarkan fungsi keanggotaan tertentu. Nilai linguistik adalah penamaan suatu grup yang mewakili keadaan atau kondisi tertentu dengan menggunakan bahasa alami, misalnya variabel linguistik kecepatan putaran motor servo, terbagi dalam 3 nilai yaitu: Cepat, Normal, Lambat [2], [3].

\section{5) Sistem Inferensi Fuzzy}

Salah satu aplikasi logika fuzzy yang telah berkembang amat luas dewasa ini adalah sistem inferensi fuzzy (Fuzzy Inference System/FIS), yaitu sistem komputasi yang bekerja atas dasar prinsip penalaran fuzzy, seperti halnya manusia melakukan penalaran dengan nalurinya. Terdapat dua jenis sistem inferensi fuzzy yang digunakan secara luas dalam berbagai aplikasi, yaitu:

\section{a) Fuzzy menurut Mamdani}

Sistem inferensi fuzzy metode Mamdani dikenal juga dengan nama metode Max-Min. Metode Mamdani bekerja berdasarkan aturanaturan linguistik. Metode ini diperkenalkan oleh Ebrahim H. Mamdani pada tahun 1975. Untuk mendapatkan output (hasil), diperlukan 4 tahapan:

\section{b) Fuzzy menurut Sugeno}

Penalaran metode Sugeno ini hampir sama dengan penalaran Mamdani, hanya saja output sistem tidak berupa himpunan fuzzy, melainkan berupa konstanta atau persamaan linear. Metode ini diperkenalkan oleh Takagi-Sugeno Kang pada tahun 1985.

\section{6) Defuzzifikasi}

Defuzzifikasi merupakan kebalikan dari fuzzifikasi, yaitu pemetaan dari himpunan fuzzy ke himpunan tegas. Input dari proses defuzzifikasi adalah suatu himpunan fuzzy yang diperoleh dari komposisi aturan-aturan fuzzy. Hasil dari defuzzifikasi ini merupakan output dari sistem kendali logika fuzzy.

\section{Perancangan Sistem}

Gambar 9 merupakan diagram blok sistem dari prototipe pengontrol arah pancaran radar yang digunakan untuk mematikan dan menghidupkan pancaran radar. Secara garis besar sistem terdiri dari empat blok, yaitu blok catu daya, kontroler, sensor, dan motor.

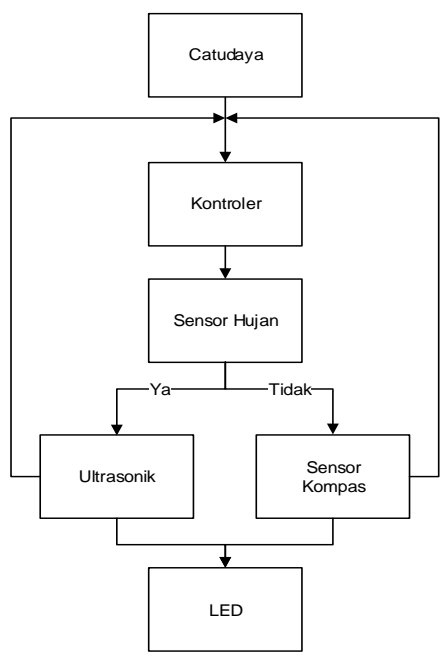

Gambar 9. Diagram Blok Keseluruhan.

Keterangan dari diagram blok radar Gambar 9:

- Catu daya berfungsi sebagai pemberi masukan daya pada sistem.

- Motor servo berfungsi sebagai pemutar radar.

- Ultrasonik berfungsi untuk memberi masukan kepada blok kontroler dan menerima keluaran blok kontroler.

- Sensor kompas berfungsi sebagai pemberi masukan kepada blok kontroler dan penerima keluaran blok kontroler.

- Kontroler berfungsi sebagai penerima masukan dari ultrasonik dan sensor kompas dan berfungsi sebagai pengatur LED dan gerakan motor.

- LED berfungsi sebagai penanda keluaran yang dihasilkan.

\section{A. Perancangan Blok Diagram Sistem}

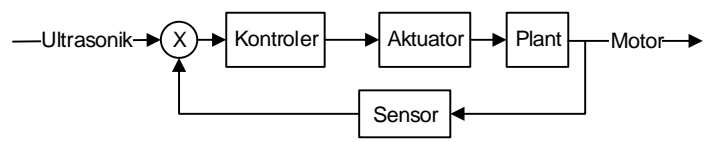

Gambar 10. Diagram Blok Sistem.

Pada perancangan blok diagram (Gambar 10) ini terdapat aliran berjalannya sistem. Tujuan adanya blok diagram sistem supaya alur perjalanan sistem dapat sesuai. Jika terdapat kesalahan, sistem dapat mengetahui dari tiap blok yang bermasalah. Sistem dimulai dari 
adanya input yang berupa ada tidaknya halangan yang dibaca oleh sensor ultrasonik. Input akan diteruskan melalui beberapa blok di antaranya kontroler, aktuator dan plant. Dari beberapa blok tersebut akan mengeluarkan sebuah output. Jika dari beberapa blok tersebut tidak sesuai dan terbaca oleh sensor maka akan mengulang masuk kembali ke beberapa blok untuk mengeluarkan keluaran yang sesuai dengan yang dikontrol.

\section{B. Perancangan Tiang Agung}

Tiang Agung merupakan tiang yang berada pada kapal yang berguna untuk meletakkan radar dan tali-tali penyangga layar. Pada prototipe kali ini dibuat prototipe tiang agung dengan menggunakan bentuk bangun menyerupai tiang dengan bidang yang berbeda-beda. Bidang yang berbeda tersebut dimaksudkan untuk menguji pembacaan sensor ultrasonik terhadap bidang pantul yang dibaca.

Prototipe tiang agung ini dirancang penempatannya menetap, supaya menyerupai tiang agung sebenarnya. Namun bentuk bidangnya saja yang berbeda-beda. Prototipe tiang agung ini berdiri sendiri tidak menggunakan catuan dan pengiriman data. Maka tidak diperlukannya peralatan lainnya sebagai pendukung tiang agung.

Diagram alir sistem dapat dilihat pada gambar berikut ini,

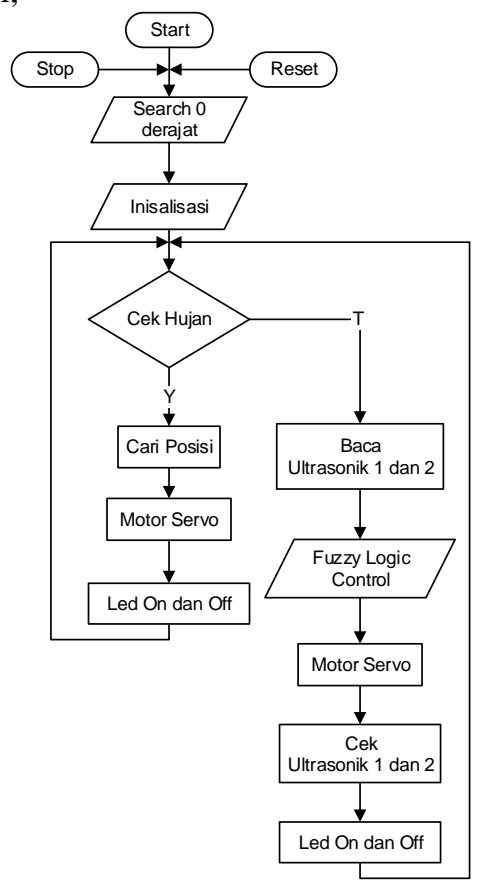

Gambar 11 Diagram Alir Sistem.

Dalam diagram alir pada Gambar 11 terdapat beberapa bagian untuk sistem bekerja, yang dimulai dengan start power dihidupkan terlebih dahulu. Pada saat pertama kali dihidupkan, sistem ini akan menjalankan sistem inisialisasi. Inisialisai ini akan mengidentifikasi sudut setting point tiang agung dilihat dari radar dengan sensor kompas. Jika sudut setting point sudah ditemukan maka akan disimpan untuk menjalankan program pada saat tertentu.

Pada saat kondisi normal, sistem ini akan bekerja menggunakan dua sensor ultrasonik yang dipasang di pinggir radar. Hal ini bertujuan jika salah satu sensor ultrasonik mengenai halangan maka pancaran radar akan mati namun radar tetap berputar. Jika kondisi cuaca tidak normal misalkan kondisi hujan maka akan berjalan dengan inisialisasi yang sudah didapatkan. Jadi radar dapat digunakan di setiap kondisi yang terjadi.

Dalam sistem ini digunakan kontrol logika samar untuk pendeteksian tiang, dengan parameter jarak tiang dengan radar. Parameter ini akan mempengaruhi cepat lambatnya kecepatan putar motor servo. Jika jarak pancaran mendekati tiang agung maka pergerakan motor akan lebih cepat begitu sebaliknya. Sistem ini akan berulang terus menerus selama alat ini dihidupkan. Untuk mengakiri sistem ini maka alat ini harus di-mode off atau dimatikan.

\section{Pengujian dan Analisis}

Tujuan pengujian performa keselurahan sistem ini adalah untuk mengetahui bagaimana sistem ini dapat berjalan dengan perpaduan sistem-sistem yang menunjang untuk alat ini.

Sebelum melakukan pengujian ini sistem harus terlebih dahulu hardware-nya digabungkan. Lalu program-progam yang digabungkan disusun secara sendiri-sendiri. Dengan mengacu diagram alir, dibuat sebuah program supaya progam yang dijalankan sesuai dengan diagram alirnya. Setelah itu sistem dihidupkan, dengan sendirinya sistem akan menentukan setting point di titik $0^{\circ}$ lalu dilanjutkan inisialisasi untuk program utama. Setiap sensor membaca data, akan ditampilkan dalam LCD dan begitu seterusnya. Dalam sistem ini terdapat 4 kondisi, yakni kondisi tidak hujan belum inisialisasi, kondisi tidak hujan sudah inisialisasi, kondisi hujan belum inisialisasi, dan kondisi hujan sudah inisialisasi. Dalam pengujian ini dibagi beberapa tahap berdasar kondisi yang sedang berlangsung. Data pengujian meliputi lama waktu pembacaan sensor, kecepatan putar tiap kondisi, ketetapan titik baca sudut untuk menentukan sudut deviasi.

\section{A. Hasil Pengujian}

\section{1) Penentuan Set Point}

Dalam hal pertama kali alat dihidupkan, akan berputar mencari sudut $0^{\circ}$, dalam pencarian sudut ini memerlukan satu atau beberapa putaran dan pembacaan di tempat sesuai rentang $350-10^{\circ}$. Data pengujian ada dalam Tabel 1 sebagai berikut.

TABEL I

Pengujian Set Point Titik $0^{\circ}$

\begin{tabular}{|c|c|c|c|}
\hline No. & Sudut 0 $\left(^{\circ}\right)$ & $\begin{array}{c}\text { Jumlah } \\
\text { Putaran }\end{array}$ & $\begin{array}{c}\text { Sudut } \\
\text { Sebenarnya }\left(^{\circ}\right)\end{array}$ \\
\hline 1 & 0 & 1 & 20 \\
\hline 2 & 0 & 2 & 10 \\
\hline 3 & 0 & 1 & 15 \\
\hline 4 & 0 & 1 & 10 \\
\hline 5 & 0 & 2 & 17 \\
\hline 6 & 0 & 3 & 13 \\
\hline 7 & 0 & 1 & 5 \\
\hline 8 & 0 & 1 & 8 \\
\hline 9 & 0 & 1 & 12 \\
\hline 10 & 0 & 1 & 5 \\
\hline
\end{tabular}


Dalam pengujian set point titik $0^{\circ}$, didapatkan beberapa data yang cocok dan ada beberapa yang tidak cocok dalam program. Dalam $10 \mathrm{kali}$ percobaan terdapat 5 error yang tidak sesuai dengan data rentang yang telah ditetapkan. Hal ini disebabkan karena faktor kecepatan motor servo dalam berputar, sehingga data sensor kompas belum sampai mengirimkan sudut yang telah terbaca dan sudah beralih ke sudut yang lain. Dari pengujian pertama maka didapatkan set point ,juga besar Pulse Wave Modulation (PWM) yang tepat yang harus digunakan.

\section{2) Penentuan Sudut Inisialisasi}

Setelah set point titik $0^{\circ}$ ditemukan, program akan berlanjut untuk melakukan perintah selanjutnya. Perintah selanjutnya ini dinamakan pengujian sudut inisialisasi. Inisialisasi tersebut untuk menentukan titik awal dan titik akhir sensor membaca tiang. Hal ini digunakan untuk kondisi khusus jika sensor ultrasonik tidak mampu bekerja. Untuk lebih jelasnya dalam Tabel 2 .

TABEL II

PENGUJIAN TITIK INISIALISAS

\begin{tabular}{|c|c|c|c|c|c|}
\hline \multirow{2}{*}{ No. } & \multirow{2}{*}{$\begin{array}{c}\text { Jarak } \\
(\mathbf{c m})\end{array}$} & \multicolumn{3}{|c|}{ Sudut $\left(^{\circ}\right)$} & Kecepatan \\
\cline { 3 - 5 } & & Data 1 & Data 2 & Deviasi & $\begin{array}{c}\text { PWM }) \\
(\mathbf{r p m})\end{array}$ \\
\hline 1 & 60 & 20,4 & 49,7 & 29,3 & 1037 \\
\hline 2 & 60 & 19,9 & 48,6 & 28,7 & 1037 \\
\hline 3 & 60 & 21,1 & 49,6 & 28,5 & 1037 \\
\hline 4 & 80 & 19,7 & 41,3 & 21,6 & 1037 \\
\hline 5 & 80 & 19,6 & 41,5 & 21,9 & 1037 \\
\hline 6 & 80 & 19,3 & 41,1 & 21,8 & 1037 \\
\hline 7 & 100 & 19,8 & 36,7 & 16,9 & 1037 \\
\hline 8 & 100 & 20,6 & 37,2 & 16,6 & 1037 \\
\hline 9 & 100 & 19,2 & 36,8 & 17,6 & 1037 \\
\hline 10 & 120 & 18,7 & 33,2 & 14,5 & 1037 \\
\hline 11 & 120 & 18,9 & 34,1 & 15,2 & 1037 \\
\hline 12 & 120 & 20,1 & 34,8 & 14,7 & 1037 \\
\hline
\end{tabular}

Dalam pengujian inisialisasi dengan rentang ordinat $14,7-29,3^{\circ}$ sebagai sudut deviasi pada tiang. Percobaan dilakukan 8 kali percobaan dengan lebar tiang $30 \mathrm{~cm}$ dan jangkauan utrasonik $60-120 \mathrm{~cm}$. Dengan melihat data-data pada tabel maka dapat diperoleh kesimpulan bahwa semakin jauh jarak prototipe radar dengan prototipe tiang agung maka sudut deviasi akan semakin kecil. Hal ini selaras dalam teori pitagoras yang sudah diterapkan dalam perhitungan trigonometri. Sedangkan untuk data PWM tidak berubah karena dalam program inisialisasi tidak dimasukkan program fuzzy jadi PWM dalam keaadaan normal.

\section{B. Pengujian Penentuan Kondisi}

Dalam pengujian ini merupakan program lanjutan dari program inisialisasi. Terdapat 4 kondisi sebagai berikut,

\section{1) Kondisi tidak hujan dan belum inisialisasi}

Data pengujian pada kondisi tidak hujan dan belum inisialisasi ditampilkan pada Tabel 3 sebagai berikut.
TABEL III

TIDAK HUJAN BELUM INISIALISAS

\begin{tabular}{|c|c|c|c|c|c|c|}
\hline \multirow{2}{*}{ No } & \multirow{2}{*}{$\begin{array}{c}\text { Jarak } \\
(\mathbf{c m})\end{array}$} & \multicolumn{2}{|c|}{$\begin{array}{c}\text { Kecepatan (PWM) } \\
(\mathbf{r p m})\end{array}$} & \multicolumn{3}{|c|}{ Sudut $\left(^{\circ}\right)$} \\
\cline { 3 - 7 } & & $\begin{array}{c}\text { Waktu } \\
\text { Pancar }\end{array}$ & $\begin{array}{c}\text { Waktu } \\
\text { Mati }\end{array}$ & Data 1 & Data 2 & Deviasi \\
\hline 1 & 60 & 1037 & 1037 & 20,4 & 49,7 & 29,3 \\
\hline 2 & 60 & 1037 & 1037 & 19,6 & 48,5 & 28,9 \\
\hline 3 & 80 & 1037 & 1037 & 18,9 & 41,6 & 22,7 \\
\hline 4 & 80 & 1037 & 1037 & 19,7 & 41,3 & 21,6 \\
\hline 5 & 100 & 1037 & 1037 & 20,6 & 37,2 & 16,6 \\
\hline 6 & 100 & 1037 & 1037 & 19,1 & 36,9 & 17,8 \\
\hline 7 & 120 & 1037 & 1037 & 19,8 & 35,1 & 15,3 \\
\hline 8 & 120 & 1037 & 1037 & 20,1 & 34,8 & 14,7 \\
\hline
\end{tabular}

Dalam kondisi ini radar belum melakukan inisialisasi dan kondisi di luar tidak hujan maka radar dapat bekerja dengan memanfaatkan sensor ultrasonik, untuk pembacaan sensor kompas secara manual dengan kompas biasa. Untuk kontrol logika fuzzy belum bekerja karena fuzzy bekerja pada program yang sudah diinisialisasi. Dalam hal ini maka LCD akan menampilakan "INISIALISASI".

\section{2) Kondisi tidak hujan dan sudah inisialisasi}

Data pengujian pada kondisi tidak hujan dan sudah inisialisasi disajikan pada Tabel 4 sebagai berikut

TABEL IV

TIDAK HUJAN SUDAH INISIALISASI

\begin{tabular}{|c|c|c|c|c|c|c|}
\hline \multirow{2}{*}{ No. } & \multirow{2}{*}{$\begin{array}{c}\text { Jarak } \\
(\mathbf{c m})\end{array}$} & \multicolumn{2}{|c|}{$\begin{array}{c}\text { Kecepatan (PWM) } \\
\text { (rpm) }\end{array}$} & \multicolumn{3}{|c|}{ Sudut $\left(^{\circ}\right.$ ) } \\
\cline { 3 - 7 } & & $\begin{array}{c}\text { Waktu } \\
\text { Pancar }\end{array}$ & $\begin{array}{c}\text { Waktu } \\
\text { Mati }\end{array}$ & Data 1 & Data 2 & Deviasi \\
\hline 1 & 60 & 1037 & 1010 & 21,1 & 49,6 & 28,5 \\
\hline 2 & 60 & 1037 & 1011 & 19,7 & 48,3 & 28,6 \\
\hline 3 & 80 & 1037 & 1001 & 19,3 & 41,1 & 21,8 \\
\hline 4 & 80 & 1037 & 1002 & 19,7 & 40,8 & 21,1 \\
\hline 5 & 100 & 1037 & 991 & 20,9 & 36,9 & 16 \\
\hline 6 & 100 & 1037 & 992 & 19,2 & 36,8 & 17,6 \\
\hline 7 & 120 & 1037 & 981 & 18,9 & 34,1 & 15,2 \\
\hline 8 & 120 & 1037 & 980 & 20,3 & 34,6 & 14,3 \\
\hline
\end{tabular}

Dalam kondisi ini radar sudah melakukan inisialisasi dan kondisi di luar tidak hujan maka radar dapat bekerja dengan memanfaatkan semua sensor dan logika fuzzy. Dalam hal ini dapat dilihat berdasarkan tabel bahwa logika fuzzy mampu berjalan berdasarkan jauh tidaknya tiang yang terdeteksi oleh sensor ultrasonik. Oleh sebab itu sudut deviasi dan jarak dapat ditampilkan dalam LCD. Sehingga alat bisa terkontrol sebagaimana mestinya.

\section{3) Kondisi hujan dan belum inisialisasi}

Data pengujian pada kondisi hujan dan belum inisialisasi ditampilkan pada Tabel 5 sebagai berikut. 
TABEL V

HUJAN BELUM INISIALISASI

\begin{tabular}{|c|c|c|c|c|c|c|}
\hline \multirow{2}{*}{ No. } & \multirow{2}{*}{$\begin{array}{c}\text { Jarak } \\
(\mathbf{c m})\end{array}$} & $\begin{array}{c}\text { Kecepatan (PWM) } \\
(\mathbf{r p m})\end{array}$ & \multicolumn{3}{|c|}{ Sudut $\left(^{\circ}\right)$} \\
\hline & & $\begin{array}{c}\text { Waktu } \\
\text { Pancar }\end{array}$ & $\begin{array}{c}\text { Waktu } \\
\text { Mati }\end{array}$ & Data 1 & Data 2 & Deviasi \\
\hline 1 & 60 & 1037 & 1037 & & & \\
\hline 2 & 60 & 1037 & 1037 & & & \\
\hline 3 & 80 & 1037 & 1037 & & & \\
\hline 4 & 80 & 1037 & 1037 & & & \\
\hline 5 & 100 & 1037 & 1037 & & & \\
\hline 6 & 100 & 1037 & 1037 & & & \\
\hline 7 & 120 & 1037 & 1037 & & & \\
\hline 8 & 120 & 1037 & 1037 & & & \\
\hline
\end{tabular}

Dalam kondisi ini radar belum melakukan inisialisasi dan kondisi di luar hujan maka radar tidak dapat bekerja. Hal ini disebabkan sensor ultrasonik akan rusak apabila terkena hujan maka sensor ultrasonik akan dimatikan programnya. Begitu juga dengan sensor kompas yang belum diinisialisasi menyebabkan data ordinat tiang agung belum terdeteksi oleh sensor ultrasonik. Dalam hal ini akan tertanda LED kedipkedip dan dalam LCD akan menapilkan "WARNING RADAR USELESS”.

4) Kondisi hujan dan sudah inisialisasi.

TABEL VI

HUJAN SUDAH INISIALISASI

\begin{tabular}{|c|c|c|c|c|c|c|}
\hline \multirow{2}{*}{ No. } & \multirow{2}{*}{$\begin{array}{c}\text { Jarak } \\
(\mathbf{c m})\end{array}$} & $\begin{array}{c}\text { Kecepatan (PWM) } \\
(\mathbf{r p m})\end{array}$ & \multicolumn{3}{|c|}{ Sudut $\left(^{\circ}\right)$} \\
\cline { 3 - 7 } & & $\begin{array}{c}\text { Waktu } \\
\text { Pancar }\end{array}$ & $\begin{array}{c}\text { Waktu } \\
\text { Mati }\end{array}$ & Data 1 & Data 2 & Deviasi \\
\hline 1 & 60 & 1037 & 1037 & 20,6 & 48,8 & 28,2 \\
\hline 2 & 60 & 1037 & 1037 & 19,9 & 48,6 & 28,7 \\
\hline 3 & 80 & 1037 & 1037 & 19,6 & 41,5 & 21,9 \\
\hline 4 & 80 & 1037 & 1037 & 19,4 & 40,9 & 21,5 \\
\hline 5 & 100 & 1037 & 1037 & 20,3 & 37,1 & 16,8 \\
\hline 6 & 100 & 1037 & 1037 & 19,8 & 36,7 & 16,9 \\
\hline 7 & 120 & 1037 & 1037 & 18,7 & 33,2 & 14,5 \\
\hline 8 & 120 & 1037 & 1037 & 20,3 & 35,1 & 14,8 \\
\hline
\end{tabular}

Dalam kondisi ini radar sudah melakukan inisialisasi dan kondisi di luar hujan maka radar dapat bekerja dengan memanfaatkan data yang sudah terinisialisasi. Radar dapat bekerja namun logika fuzzy tidak dapat bekerja karena sensor ultrasonik tidak dapat mengirimkan data karena kondisi di luar hujan. Dalam hal ini akan ditampilkan "DETECTING" jika hujan sudah berhenti dan "WARNING RADAR USELESS" jika kondisi hujan masih berlangsung.

\section{Analisis Pengujian Keseluruhan}

Setelah semua pengujian berlangsung maka didapatkan beberapa data dengan beberapa parameter yang ditentukan. Maka dapat disimpulkan bahwa alat ini bekerja harus dalam keadaan kondisi di luar tidak hujan dan harus inisialisasi dahulu. Jika alat ini belum inisisalisasi maka harus bekerja menggunakan sensor ultrasonik dan jika hujan maka alat ini hanya bisa bekerja jika sudah melakukan inisialisasi. Oleh sebab itu inisialisasi awal sangat perlu untuk menunjang kinerja alat ini.
Untuk logika fuzzy yang berfungsi dalam hal ini untuk menghindari halangan yang terbaca oleh sensor ultrasonik. Jadi logika fuzzy diperlukan untuk mempercepat putaran motor servo jika sensor ultrasonik mengenai suatu halangan. Cepat lambatnya putaran motor ini ditentukan oleh jauh dekatnya tiang yang terbaca oleh sensor ultrasonik. Penggunaan 2 input sensor ultrasonik membuat sudut deviasi radar semakin besar sehingga membuat rentang pancaran radar yang aman terhadap suatu halangan.

Dari semua yang diujikan maka diperoleh set point 0 dengan rentang $356-4^{\circ}$. Dengan didapatkan sudut deviasi tiang dengan rentang ordinat $14,3-29,3^{\circ}$ dan error $\pm 3^{\circ}$. Percobaan dilakukan 8 kali percobaan dengan lebar tiang $30 \mathrm{~cm}$ dan jangkauan ultrasonik 60$120 \mathrm{~cm}$. Berdasarkan pada pengujian tersebut diperoleh bahwa pengujian sebanding dengan perbandingan teori perhitungan trigonometri penerapan rumus pitagoras. Sedangkan logika fuzzy menggunakan 3 parameter fuzzy senilai $80 \mathrm{~cm}, 140 \mathrm{~cm}$ dan $200 \mathrm{~cm}$ untuk mengatur kecepatan motor servo. Kecepatan yang diperoleh saat fuzzy berlangsung sebesar 20 kali dari kecepatan normal. Dari data yang dihasilkan prototipe ini memperoleh keberhasilan sebesar $85 \%$ dilihat dari pengujian beberapa sensor dan peggabungannya. Oleh sebab itu dari keberhasilan prototipe ini diharapkan dapat sebagai acuan dalam pembuatan radar sesungguhnya.

\section{KESIMPULAN}

Telah dirancang pengontrol arah pancaran radar pengawas pantai. Setelah dilakukan perancangan dan pengujian pada alat ini maka diperoleh sudut deviasi dengan rentang $14,3-29,3^{\circ}$ dan error $\pm 3^{\circ}$. Dengan acuan jangkauan titik tiang agung $60-120 \mathrm{~cm}$ dari poros radar dengan lebar tiang $30 \mathrm{~cm}$. Kecepatan yang diperoleh saat fuzzy berlangsung sebesar 20 kali dari kecepatan normal saat prototipe mengenai halangan. Dilihat dari data setiap pengujian sensor dan penggabungan beberapa sensor maka dapat disimpulkan bahwa keberhasilan prototipe ini sebesar $85 \%$, sehingga akan dapat sebagai acuan untuk pembuatan radar sesungguhnya.

\section{UCAPAN TERIMA KASIH}

Ucapan terima kasih kepada Puslit Elektronika dan Telekomunikasi dan Fakultas teknik Elektro Universitas Telkom Bandung atas bantuan dan kerjasamanya, sehingga penelitian ini terwujud.

\section{Daftar Pustaka}

[1] M. Wahab, P. Daud, Y. Wahyu, dan R. S. Kayatmo, "Rancang bangun radar pengawas pantai INDRA II di PPET LIPI", Prosiding seminar Radar Nasional, 2008, hal. 1-6.

[2] M. I. Sklonik, Introduction to Radar System, New York: McGraw Hill, 2002

[3] M. I. Sklonik, Radar Hand Book, $2^{\text {nd }}$ ed., Boston: McGraw Hill, 1990.

[4] S. Kusumadewi dan P. Hari, Aplikasi Logika Fuzzy untuk Mendukung Keputusan, Yogyakarta: Graha Ilmu, 2004.

[5] S. Kusumadewi, Analisis dan Desain Sistem Fuzzy, Yogyakarta: Graha Ilmu, 2002.

[6] J. Jantzen, Foundations of Fuzzy Control, London: JohnWiley \& Sons Ltd, 2007. 
